\title{
Study of Thermodynamic and Transport Properties of Glycine, Diglycine, and Triglycine in Aqueous Tartrazine at Different Temperatures
}

\author{
Anwar Ali, Rajan Patel, Shahjahan Khan, and Vidiksha Bhushan \\ Department of Chemistry, Jamia Millia Islamia (Central University), New Delhi - 110 025, India. \\ Reprint requests to A. A.; E-mail: anwarali.chem@gmail.com and anwar_jmi@yahoo.co.in \\ Z. Naturforsch. 64a, 758 - 764 (2009); received January 15, 2009
}

\begin{abstract}
The densities $(\rho)$, viscosities $(\eta)$, and refractive indices $\left(n_{\mathrm{D}}\right)$ of $(0.01,0.05,0.10,0.15$, and $0.20 \mathrm{~m})$ amino acid, glycine, and peptides, diglycine and triglycine in $0.01 \mathrm{~m}$ aqueous tartrazine solution were determined at $288.15,293.15,298.15,303.15,308.15$, and $313.15 \mathrm{~K}$. The density data were utilized to evaluate apparent molar volumes $\left(\phi_{\mathrm{v}}\right)$ which, in turn, were used to determine partial molar volumes $\left(\phi_{\mathrm{v}}{ }^{\circ}\right)$ using Masson's equation. The transfer volumes were also calculated. The viscosity data were analyzed using the Jones-Dole equation to determine the viscosity coefficients and the activation parameters. The activation parameters of viscous flow were obtained to throw light on the mechanism of viscous flow. The molar refraction was calculated using the refractive index data. The results were interpreted in the light of ion-ion, ion-nonpolar, and nonpolar-nonpolar interactions and the effect of increasing hydrophobicity as we move from glycine to triglycine on these interactions in presence of the dye tartrazine was also investigated.
\end{abstract}

Key words: Amino Acid; Peptides; Tartrazine; Partial Molar Volume;

Viscosity $A$ - and $B$-coefficients; Interactions.

\section{Introduction}

Macromolecules such as proteins, nucleic acids, and polysaccharides are evolutionary and prone to aqueous surroundings [1]. The structural units of proteins, such as amino acids, peptides, and their derivatives, are used as model compounds to study the conformational stability and behaviour of proteins in solutions.

The present work is a continuation of our program on the study of molecular interactions of amino acids/peptides in the presence of an additive tartrazine in aqueous medium from the measurement of various transport and thermodynamic properties [2-4]. Literature survey reveals that no studies have been carried out on these systems from the viewpoint of their thermodynamic and transport behaviours.

Azo colourants, such as tartrazine (E102), sunset yellow (E110), and allura red (E129), constitute one of the major synthetic colourant groups, used commercially in food, drinks, medicines, and cosmetics [5]. The dyes are widely used due to an inexpensive production and a large colour spectrum that can be obtained, when compared with natural colourants [6]. However, inspite of its commercial use, tartrazine is reported to catalyze hyperactivity [7], asthma $[8,9]$, migraines, thyroid cancer [10], and other behavioural problems [11].

Thus, keeping these considerations, experimentally measured densities $(\rho)$, viscosities $(\eta)$, and refractive indices $\left(n_{\mathrm{D}}\right)$ of aqueous tartrazine $(0.01 \mathrm{~m})$ and of solutions of glycine, diglycine, and triglycine $(0.01,0.05$, $0.10,0.15$, and $0.20 \mathrm{~m}$ ) in aqueous tartrazine at 288.15 , $293.15,298.15,303.15,308.15$, and $313.15 \mathrm{~K}$ are presented. The parameters like apparent molar volume $\left(\phi_{\mathrm{v}}\right)$, partial molar volume $\left(\phi_{\mathrm{v}}{ }^{\circ}\right)$ and its experimental slope $\left(S_{\mathrm{v}}{ }^{*}\right)$, transfer volume $\left(\phi_{\mathrm{v}}{ }^{\circ}(\operatorname{tr})\right.$, viscosity $A$ - and $B$-coefficients, free energies of activation per mole of solvent $\left(\Delta \mu_{1}{ }^{\circ *}\right)$ and solute $\left(\Delta \mu_{2}{ }^{\circ *}\right)$, enthalpies $\left(\Delta H^{*}\right)$ and entropies $\left(\Delta S^{*}\right)$ of activation of viscous flow, and molar refraction $\left(R_{\mathrm{D}}\right)$ were calculated for all the amino acid/peptides in aqueous tartrazine solution from the experimental density, viscosity, and refractive index data. These parameters were discussed in terms of ionion, ion-nonpolar, and nonpolar-nonpolar interactions in the above mentioned mixtures.

\section{Experimental}

Glycine (E. Merck, Germany, mass fraction 0.99), diglycine (Acros organics, Belgium, mass fraction 0.99), and triglycine (Sigma, mass fraction 0.99) 
Table 1. Values of densities $\rho$, viscosities $\eta$, refractive indices $n_{\mathrm{D}}$, of glycine, diglycine, and triglycine in aqueous tartrazine at different temperatures.

\begin{tabular}{|c|c|c|c|c|c|c|c|c|c|c|c|c|c|}
\hline \multirow{2}{*}{$\begin{array}{c}\mathrm{m} \\
\left(\mathrm{mol} \mathrm{kg}^{-1}\right) \\
\end{array}$} & \multicolumn{6}{|c|}{$T(\mathrm{~K})$} & \multirow{2}{*}{$\begin{array}{c}\mathrm{m} \\
\left(\mathrm{mol} \mathrm{kg}^{-1}\right) \\
\end{array}$} & \multicolumn{6}{|c|}{$T(\mathrm{~K})$} \\
\hline & 288.15 & 293.15 & 298.15 & 303.15 & 308.15 & 313.15 & & 288.15 & 293.15 & 298.15 & 303.15 & 308.15 & 313.15 \\
\hline \multicolumn{7}{|c|}{ Gly + aq. Tartrazine } & 0.05 & 1.2220 & 1.0701 & 0.9426 & 0.8406 & 0.7568 & 0.6864 \\
\hline \multicolumn{7}{|c|}{$\rho\left(\mathrm{g} \mathrm{cm}^{-3}\right)$} & 0.10 & 1.2327 & 1.0790 & 0.9500 & 0.8471 & 0.7622 & 0.6910 \\
\hline 0.00 & 1.0023 & 1.0009 & 0.9994 & 0.9980 & 0.9966 & 0.9952 & 0.15 & 1.2453 & 1.0897 & 0.9594 & 0.8552 & 0.7692 & 0.6971 \\
\hline 0.01 & 1.0028 & 1.0013 & 0.9997 & 0.9982 & 0.9967 & 0.9952 & 0.20 & 1.2579 & 1.1004 & 0.9687 & 0.8635 & 0.7768 & 0.7037 \\
\hline 0.05 & 1.0042 & 1.0025 & 1.0008 & 0.9992 & 0.9976 & 0.9960 & \multicolumn{7}{|c|}{$n_{\mathrm{D}}$} \\
\hline 0.10 & 1.0057 & 1.0039 & 1.0022 & 1.0005 & 0.9988 & 0.9971 & 0.00 & 1.3558 & 1.3553 & 1.3548 & 1.3543 & 1.3538 & 1.3533 \\
\hline 0.15 & 1.0072 & 1.0054 & 1.0036 & 1.0019 & 1.0001 & 0.9983 & 0.01 & 1.3561 & 1.3556 & 1.3552 & 1.3545 & 1.3540 & 1.3536 \\
\hline 0.20 & 1.0087 & 1.0069 & 1.0051 & 1.0033 & 1.0015 & 0.9996 & 0.05 & 1.3577 & 1.3573 & 1.3568 & 1.3563 & 1.3558 & 1.3553 \\
\hline \multicolumn{7}{|c|}{$10^{3} \cdot \eta\left(\mathrm{N} \mathrm{m}^{-2} \mathrm{~s}\right)$} & 0.10 & 1.3602 & 1.3597 & 1.3592 & 1.3587 & 1.3582 & 1.3576 \\
\hline 0.00 & 1.2105 & 1.0613 & 0.9357 & 0.8353 & 0.7526 & 0.6833 & 0.15 & 1.3625 & 1.3620 & 1.3616 & 1.3610 & 1.3605 & 1.3599 \\
\hline 0.01 & 1.2134 & 1.0631 & 0.9367 & 0.8358 & 0.7527 & 0.6833 & 0.20 & 1.3649 & 1.3644 & 1.3640 & 1.3634 & 1.3629 & 1.3623 \\
\hline 0.05 & 1.2189 & 1.0670 & 0.9397 & 0.8381 & 0.7543 & 0.6843 & \multirow{2}{*}{\multicolumn{7}{|c|}{ Trigly + aq. Tartrazine }} \\
\hline 0.10 & 1.2245 & 1.0716 & 0.9436 & 0.8413 & 0.7568 & 0.6865 & & & & & & & \\
\hline 0.15 & 1.2308 & 1.0768 & 0.9476 & 0.8447 & 0.7600 & 0.6893 & 0.00 & 1.0023 & 1.0009 & 0.9994 & 0.9980 & 0.9966 & 0.9952 \\
\hline \multirow[t]{2}{*}{0.20} & 1.2372 & 1.0820 & 0.9521 & 0.8485 & 0.7632 & 0.6923 & 0.01 & 1.0029 & 1.0014 & 0.9998 & 0.9983 & 0.9968 & 0.9953 \\
\hline & & & $n_{\mathrm{D}}$ & & & & 0.05 & 1.0059 & 1.0043 & 1.0026 & 1.0011 & 0.9995 & 0.9979 \\
\hline 0.00 & 1.3558 & 1.3553 & 1.3548 & 1.3543 & 1.3538 & 1.3533 & 0.10 & 1.0096 & 1.0080 & 1.0063 & 1.0046 & 1.0030 & 1.0013 \\
\hline 0.01 & 1.3559 & 1.3554 & 1.3549 & 1.3544 & 1.3538 & 1.3533 & 0.15 & 1.0135 & 1.0118 & 1.0101 & 1.0084 & 1.0067 & 1.0050 \\
\hline 0.05 & 1.3566 & 1.3560 & 1.3554 & 1.3548 & 1.3543 & 1.3537 & 0.20 & 1.0172 & 1.0155 & 1.0138 & 1.0122 & 1.0105 & 1.0087 \\
\hline 0.10 & 1.3576 & 1.3569 & 1.3563 & 1.3557 & 1.3551 & 1.3545 & \multicolumn{7}{|c|}{$10^{3} \cdot \eta\left(\mathrm{N} \mathrm{m}^{-2} \mathrm{~s}\right)$} \\
\hline 0.15 & 1.3584 & 1.3577 & 1.3571 & 1.3565 & 1.3559 & 1.3552 & 0.00 & 1.2105 & 1.0613 & 0.9357 & 0.8353 & 0.7526 & 0.6833 \\
\hline 0.20 & 1.3591 & 1.3585 & 1.3579 & 1.3572 & 1.3566 & 1.3559 & 0.01 & 1.2242 & 1.0721 & 0.9444 & 0.8423 & 0.7581 & 0.6876 \\
\hline \multicolumn{7}{|c|}{ Digly + aq. Tartrazine } & 0.05 & 1.2497 & 1.0935 & 0.9621 & 0.8571 & 0.7703 & 0.6980 \\
\hline \multicolumn{7}{|c|}{$\rho\left(\mathrm{g} \mathrm{cm}^{-3}\right)$} & 0.10 & 1.2723 & 1.1127 & 0.9789 & 0.8714 & 0.7825 & 0.7085 \\
\hline 0.00 & 1.0023 & 1.0009 & 0.9994 & 0.9980 & 0.9966 & 0.9952 & 0.15 & 1.2938 & 1.1309 & 0.9941 & 0.8848 & 0.7941 & 0.7189 \\
\hline 0.01 & 1.0028 & 1.0013 & 0.9997 & 0.9982 & 0.9967 & 0.9952 & 0.20 & 1.3144 & 1.1486 & 1.0094 & 0.8974 & 0.8054 & 0.7289 \\
\hline 0.05 & 1.0053 & 1.0037 & 1.0020 & 1.0004 & 0.9988 & 0.9972 & \multicolumn{7}{|c|}{$n_{\mathrm{D}}$} \\
\hline 0.10 & 1.0087 & 1.0070 & 1.0052 & 1.0035 & 1.0017 & 1.0000 & 0.00 & 1.3558 & 1.3553 & 1.3548 & 1.3543 & 1.3538 & 1.3533 \\
\hline 0.15 & 1.0116 & 1.0099 & 1.0081 & 1.0063 & 1.0045 & 1.0028 & 0.01 & 1.3568 & 1.3565 & 1.3563 & 1.3560 & 1.3556 & 1.3550 \\
\hline 0.20 & 1.0145 & 1.0127 & 1.0109 & 1.0091 & 1.0073 & 1.0055 & 0.05 & 1.3600 & 1.3598 & 1.3595 & 1.3592 & 1.3589 & 1.3586 \\
\hline \multicolumn{7}{|c|}{$10^{3} \cdot \eta\left(\mathrm{N} \mathrm{m}^{-2} \mathrm{~s}\right)$} & 0.10 & 1.3638 & 1.3635 & 1.3631 & 1.3628 & 1.3625 & 1.3621 \\
\hline 0.00 & 1.2105 & 1.0613 & 0.9357 & 0.8353 & 0.7526 & 0.6833 & 0.15 & 1.3670 & 1.3666 & 1.3664 & 1.3660 & 1.3657 & 1.3653 \\
\hline 0.01 & 1.2138 & 1.0635 & 0.9373 & 0.8364 & 0.7531 & 0.6833 & 0.20 & 1.3705 & 1.3701 & 1.3697 & 1.3693 & 1.3688 & 1.3683 \\
\hline
\end{tabular}

were used after recrystallization from ethanol/water mixtures and dried in vacuum over $\mathrm{P}_{2} \mathrm{O}_{5}$ at $\mathrm{r}$. $\mathrm{t}$. for $72 \mathrm{~h}$ before use. Analytical reagent grade, tartrazine (E. Merck, Germany, mass fraction 0.98) was used as such without further purification. Doubly distilled and deionized water was utilized for preparing $0.01 \mathrm{~m}$ aqueous tartrazine solution and was used as solvent to prepare $0.01,0.05,0.10,0.15$, and $0.20 \mathrm{~m}$ glycine, diglycine, and triglycine solutions. All the solutions were prepared by weight (molality basis) and weighings were done on Swiss-made electronic balance, Precisa XB-220A, with a precision of $\pm 0.0001 \mathrm{~g}$. The solutions were stored in special air tight bottles to avoid contamination and evaporation.

The pycnometer and Ubbelohde-type suspended level viscometer were used for the density and viscosity measurements, respectively. The methodology is described in our earlier papers [2, 12]. Refractive indices were measured using thermostated Abbe refractometer after calibrating it with double distilled water and toluene at known temperatures. The accuracy in density, viscosity, and refractive index measurements was found to be $\pm 0.1 \mathrm{~kg} \mathrm{~m}^{-3}, \pm 3 \cdot 10^{-6} \mathrm{~N} \mathrm{~s} \mathrm{~m}^{-2}$, and \pm 0.0002 , respectively.

For the measurements of density, viscosity, and refractive index, the temperature of the solutions was maintained in an electronically controlled water bath (Julabo, Germany) having a precision of $\pm 0.02 \mathrm{~K}$.

\section{Results and Discussion}

The measured density, viscosity, and refractive index for $0.01 \mathrm{~m}$ aqueous tartrazine and of 0.01 , $0.05,0.10,0.15$, and $0.20 \mathrm{~m}$ glycine, diglycine, and 


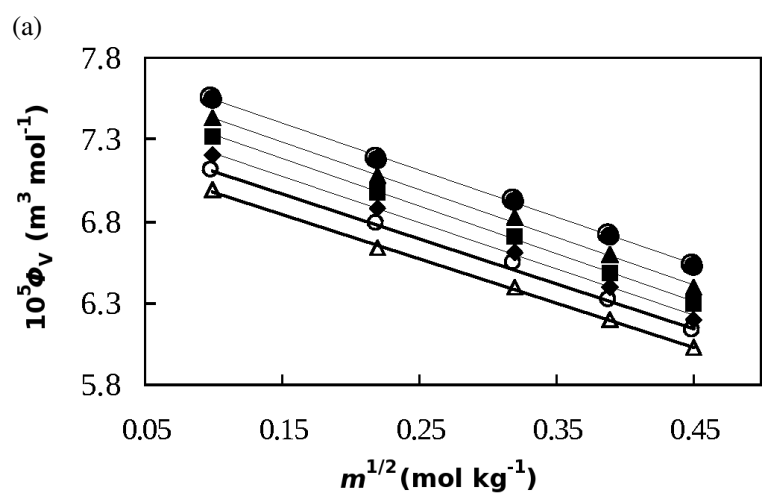

(b)

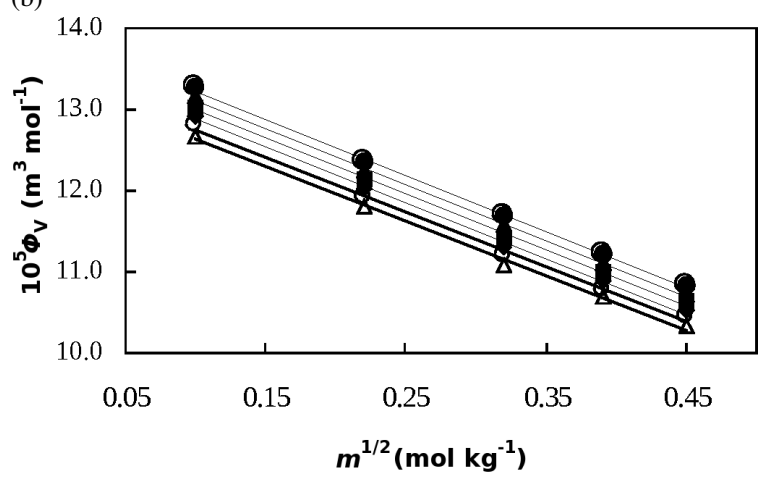

(c)

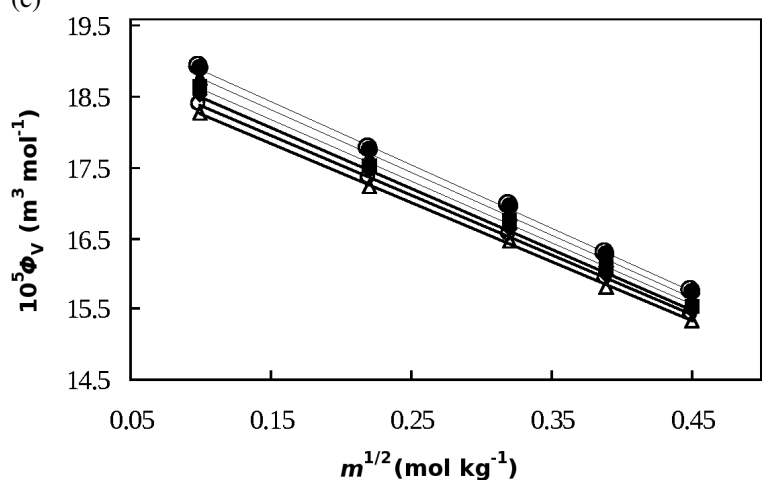

Fig. 1. Plots of apparent molar volumes $\phi_{\mathrm{v}}$ vs. $m^{1 / 2}$ of (a) glycine; (b) diglycine; (c) triglycine in aqueous tartrazine at temperature $T=\{288.15(\triangle), 293.15(\circ), 298.15(\diamond)$, $303.15(\boldsymbol{\bullet}), 308.15(\boldsymbol{\Lambda}), 313.15(\bullet)\} \mathrm{K}$

triglycine in aqueous tartrazine at $288.15,293.15$, $298.15,303.15,308.15$, and $313.15 \mathrm{~K}$ are given in Table 1 .

The apparent molar volumes of ternary solutions were determined from density data using the following relation:

$$
\phi_{\mathrm{v}}=\frac{M}{\rho}-\frac{1000\left(\rho-\rho_{0}\right)}{m \rho \rho_{0}},
$$

where $M$ is the molecular weight of solute (glycine, diglycine, and triglycine) having molality $m, \rho$ and $\rho_{0}$ are the densities of ternary solutions and solvent (aqueous tartrazine), respectively. The $\phi_{\mathrm{v}}$ values of one amino acid (glycine) and two peptides (diglycine and triglycine) at the six temperatures are plotted against $m^{1 / 2}$ as shown in Figure 1. Figure 1 shows that $\phi_{\mathrm{v}}$ is large positive for the amino acid/peptides in aqueous tartrazine solution, indicating the presence of strong solute-solvent interactions.

A valuable empirical generalization on the change of $\phi_{\mathrm{v}}$ with square root of molal concentration is given by Masson's equation [13]:

$$
\phi_{\mathrm{v}}=\phi_{\mathrm{v}}{ }^{\circ}+S_{\mathrm{v}}{ }^{*} m^{1 / 2},
$$

where $\phi_{\mathrm{v}}{ }^{\circ}$ is the partial molar volume that equals the standard partial molar volume or partial molar volume at infinite dilution and $S_{\mathrm{V}}{ }^{*}$ is the experimental slope. At infinte dilution, $m$ tends to 0 , solute-solute interactions vanish, $\phi_{\mathrm{v}}$ becomes equal to $\phi_{\mathrm{v}}{ }^{\circ}$, therefore, $\phi_{\mathrm{v}}{ }^{\circ}$ gives an insight into the solute-solvent interactions. At finite dilution, $S_{\mathrm{V}}{ }^{*}$ concerns with the solute-solute interactions. The $\phi_{\mathrm{v}}{ }^{\circ}$ and $S_{\mathrm{V}}{ }^{*}$ values are listed in Table 2 .

In general, it is expected that the following types of interactions will take place in the mixtures:

(i) ion-ion interactions between zwitterions $\left(\mathrm{NH}^{+}\right.$, $\mathrm{COO}^{-}$) of amino acids / peptides and anions $\mathrm{SO}_{3}^{-}$/ cations $\mathrm{Na}^{+}$of tartrazine $\left(\mathrm{C}_{16} \mathrm{H}_{9} \mathrm{~N}_{4} \mathrm{Na}_{3} \mathrm{O}_{4} \mathrm{~S}_{2}\right)$.

(ii) ion-nonpolar group interactions between $\left(\mathrm{NH}_{3}{ }^{+}, \mathrm{COO}^{-}\right)$of amino acid/peptides and hydrophobic group of tartrazine and between cations $\mathrm{Na}^{+} /$ anions $\mathrm{SO}^{-}{ }_{3}$ of tartrazine and hydrophic part of amino $\mathrm{acid} /$ peptides.

(iii) nonpolar-nonpolar group interactions between hydrophobic side chains of amino acid/peptides and those of the dye, tartrazine.

Table 2 shows that the $\phi_{\mathrm{v}}{ }^{\circ}$ values are found to increase from glycine to triglycine, which is due to the increase in the hydrophobicity of the alkyl chain. This points the dominance of interactions of type (ii) and (iii) over interactions of type (i).

The observed values of $S_{\mathrm{V}}{ }^{*}$ (Table 2) are smaller than $\phi_{\mathrm{V}}{ }^{\circ}$ values, implying the presence of weak solutesolute interactions. The negative values of $S_{\mathrm{v}}{ }^{*}$ are due to the reduction in volume caused by ion-nonpolar and nonpolar-nonpolar group interactions. The $S_{\mathrm{v}}{ }^{*}$ values are also found to decrease with rise in temperature for all amino acid/peptides, reflecting that the amino 


\begin{tabular}{|c|c|c|c|c|c|c|}
\hline & \multicolumn{6}{|c|}{$T(\mathrm{~K})$} \\
\hline & 288.15 & 293.15 & 298.15 & 303.15 & 308.15 & 313.15 \\
\hline & \multicolumn{6}{|c|}{ Gly + aq. Tartrazine } \\
\hline $10^{5} \cdot \phi_{\mathrm{v}}^{\circ}\left(\mathrm{m}^{3} \mathrm{~mol}^{-1}\right)$ & 7.2583 & 7.3917 & 7.5106 & 7.6242 & 7.7341 & 7.8354 \\
\hline $10^{5} \cdot S_{\mathrm{V}}{ }^{*}\left(\mathrm{~m}^{3} \mathrm{dm}^{1 / 2} \mathrm{~mol}^{-3 / 2}\right)$ & -2.7447 & -2.7910 & -2.8920 & -2.9372 & -2.9500 & -2.9158 \\
\hline $10^{5} \cdot{\phi_{\mathrm{v}}}^{\circ}$ (water) $\left(\mathrm{m}^{3} \mathrm{~mol}^{-1}\right)$ & $4.2480[14]$ & - & $4.3240[15]$ & - & $4.3790[15]$ & $4.4000[16]$ \\
\hline \multirow[t]{2}{*}{$10^{5} \cdot{\phi_{\mathrm{v}}}^{\circ}(\mathrm{tr})\left(\mathrm{m}^{3} \mathrm{~mol}^{-1}\right)$} & 3.0103 & - & 3.1866 & - & 3.3551 & 3.4354 \\
\hline & \multicolumn{6}{|c|}{ Diglycine + aq. Tartrazine } \\
\hline $10^{4} \cdot \phi_{\mathrm{v}}^{\circ}\left(\mathrm{m}^{3} \mathrm{~mol}^{-1}\right)$ & 1.3328 & 1.3450 & 1.3583 & 1.3701 & 1.3824 & 1.3949 \\
\hline $10^{5} \cdot S_{\mathrm{V}}^{*}\left(\mathrm{~m}^{3} \mathrm{dm}^{1 / 2} \mathrm{~mol}^{-3 / 2}\right)$ & -6.7976 & -6.8522 & -6.9551 & -6.9772 & -6.9899 & -7.0450 \\
\hline $10^{5} \cdot \phi_{\mathrm{v}}{ }^{\circ}$ (water) $\left(\mathrm{m}^{3} \mathrm{~mol}^{-1}\right)$ & - & - & $7.6280[17]$ & - & $7.7100[17]$ & - \\
\hline $10^{5} \cdot \phi_{\mathrm{v}}^{\circ}{ }_{(\operatorname{tr})}^{\circ}\left(\mathrm{m}^{3} \mathrm{~mol}^{-1}\right)$ & - & - & 5.9546 & - & 6.1145 & - \\
\hline \multicolumn{7}{|c|}{ Trigly + aq. Tartrazine } \\
\hline $10^{4} \cdot \phi_{\mathrm{v}}^{\circ}\left(\mathrm{m}^{3} \mathrm{~mol}^{-1}\right)$ & 1.9137 & 1.9272 & 1.9424 & 1.9552 & 1.9690 & 1.9822 \\
\hline $10^{5} \cdot S_{\mathrm{V}}{ }^{*}\left(\mathrm{~m}^{3} \mathrm{dm}^{1 / 2} \mathrm{~mol}^{-3 / 2}\right)$ & -8.5131 & -8.6249 & -8.8202 & -8.9304 & -9.0441 & -9.1009 \\
\hline $10^{4} \cdot{\phi_{\mathrm{v}}}^{\circ}$ (water) $\left(\mathrm{m}^{3} \mathrm{~mol}^{-1}\right)$ & - & - & $1.1211[18]$ & - & - & - \\
\hline $10^{5} \cdot \phi_{\mathrm{v}}{ }^{\circ}(\operatorname{tr})\left(\mathrm{m}^{3} \mathrm{~mol}^{-1}\right)$ & 一 & - & 8.2129 & - & - & 一 \\
\hline
\end{tabular}

Table 2. Values of $\phi_{\mathrm{v}}{ }^{\circ}$, $\phi_{\mathrm{V}}{ }^{\circ}$ (water), $\quad \phi_{\mathrm{V}}{ }^{\circ}$ (tr), and $S_{\mathrm{V}}{ }^{*}$ of glycine, diglycine, and triglycine of aqueous tartrazine at different temperatures.

acid/peptides act as structure-breakers in the present study.

The volumes of transfer $\left(\phi_{\mathrm{v}}{ }^{\circ}(\mathrm{tr})\right)$ for amino acid/ peptides from aqueous to aqueous tartrazine solution were calculated using $\phi_{\mathrm{v}}{ }^{\circ}$ data from the relation

$$
\phi_{\mathrm{v}}{ }^{\circ}(\mathrm{tr})=\phi_{\mathrm{v}}{ }^{\circ} \text { (aq. tartrazine) }-\phi_{\mathrm{v}}{ }^{\circ} \text { (aqueous). }
$$

The values of $\phi_{\mathrm{V}}{ }^{\circ}(\operatorname{tr})$ are included in Table 2. The $\phi_{\mathrm{v}}{ }^{\circ}(\mathrm{aq})$ were obtained from the literature [14-18]. It is evident from Table 2 that the values of $\phi_{\mathrm{v}}{ }^{\circ}$ (aqueous tartrazine) are higher than ${\phi_{\mathrm{v}}}^{\circ}$ (aqueous), resulting in positive transfer volumes for all the amino acid/peptides. The increase in the volume of solutions in presence of tartrazine leads to the positive values of $\phi_{\mathrm{v}}{ }^{\circ}(\operatorname{tr})$. This is due to the fact that amino acid/peptides under study induce a considerable contraction in volume of the peripheral solvent because of electrostriction [19]. This electrostrictive effect of amino acid/ peptides is diminished on the addition of tartrazine due to the shielding effect of tartrazine molecules on the zwitterions. The structure of tartrazine shows the presence of several possible active sites that can interact with the zwitterions of amino acids/peptides. These active sites are a lone pair of electrons on two oxygen atoms and one on each nitrogen atom, which may interact with $\mathrm{NH}_{3}^{+}$of zwitterions glycine, diglycine, and triglycine. As a result, amino acid/peptides would not be able to exert the electrostriction effect at their maximum in the presence of dye tartrazine as compared to that in the pure water, thereby, resulting in a volume expansion and, hence, in positive transfer volumes. Similar conclusions were also drawn by others for amino acids in aqueous alkali chloride solutions [20] and in aqueous tetramethylammonium bromide solutions [21] and also by Ali et al. [22] for amino acids in aqueous caffeine solution.

The variation of relative viscosity $\left(\eta_{\mathrm{r}}\right)$ for amino acid/peptides in aqueous tartrazine solution can be represented by the Jones-Dole [23] equation:

$$
\eta_{\mathrm{r}}=\frac{\eta}{\eta_{0}}=1+A m^{1 / 2}+B m
$$

where $\eta$ and $\eta_{0}$ are the respective viscosities of solution and solvent. $A$ and $B$ are the constants characteristic of ion-ion and ion-solvent interactions, respectively. $A$ and $B$ were obtained by the least-squares method as intercept and slope of the linear plots of $\left(\eta_{\mathrm{r}}-1\right) / \mathrm{m}^{1 / 2}$ versus $m^{1 / 2}$.

Eyring and co-workers [24] proposed that the contribution per mole of solvent to the free energy of activation $\left(\Delta \mu_{1}{ }^{0 *}\right)$ of viscous flow can be evaluated using the relation

$$
\eta_{0}=\left(\frac{h N_{\mathrm{A}}}{\overline{V_{1}^{0}}}\right) \exp \left(\frac{\Delta \mu_{1}^{0 *}}{R T}\right),
$$

where $h$ is the Planck constant, $N_{\mathrm{A}}$ the Avogadro's number, $\overline{V_{1}{ }^{0}}$ the partial molar volume of solvent, $R$ the universal gas constant, and $T$ the temperature. The rearrangement of the above equation (5) gives:

$$
\Delta \mu_{1}^{0 *}=R T \ln \left(\frac{\eta_{0} \overline{V_{1}^{0}}}{h N_{\mathrm{A}}}\right) .
$$

According to Feakins et al. [25] the relation of $B$ coefficient to $\Delta \mu_{2}{ }^{0 *}$, the contributation per mole of solute (amino acid/peptides) to the free energy of activa- 
Table 3. Values of Falkenhagen coefficient $A$, Jones-Dole coefficient $B$, free energy of activation per mole of solvent $\Delta \mu_{1}{ }^{0 *}$ and solute $\Delta \mu_{2}{ }^{0 *}$ of glycine, diglycine, and triglycine in aqueous tartrazine solution at different temperatures.

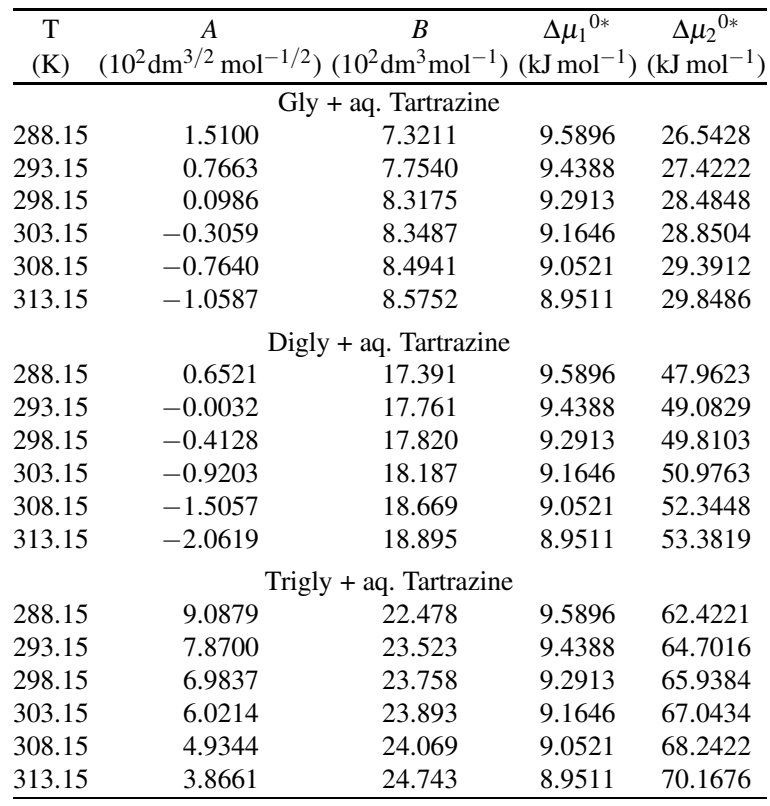

tion of viscous flow is given by

$$
B=\frac{1}{1000}\left[\left(\overline{V_{1}{ }^{0}}-\overline{V_{2}{ }^{0}}\right)+\frac{\overline{V_{1}^{0}}\left(\Delta \mu_{2}{ }^{0 *}-\Delta \mu_{1}{ }^{0 *}\right)}{R T}\right],
$$

where $\overline{V_{2}{ }^{0}}\left(=\phi_{\mathrm{v}}{ }^{0}\right)$ is the partial molar volume of the solute. The rearrangement of (7) yields:

$$
\Delta \mu_{2}{ }^{0 *}=\Delta \mu_{1}{ }^{0 *}+\frac{R T}{\overline{V_{1}}}\left[1000 B-\left(\overline{V_{1}{ }^{0}}-\overline{V_{2}{ }^{0}}\right)\right] .
$$

The calculated values of $A, B, \Delta \mu_{1}^{0 *}$, and $\Delta \mu_{2}^{0 *}$ are summarized in Table 3.

It can be observed from Table 3 that the values of $B$ coefficients are higher as compared to $A$-coefficients, thereby supporting the behaviour of $\phi_{\mathrm{v}}{ }^{\circ}$ and $S_{\mathrm{v}}{ }^{*}$, respectively.

The sign of $(\partial B / \partial T)_{\mathrm{P}}$ plays a crucial role in determining the structure-making/-breaking ability of solute rather than the size of $B$-coefficients [26]. The negative values of $(\partial B / \partial T)_{\mathrm{P}}$ signify structuremaking while positive values represent the structurebreaking ability of the solute. The variation of $B$ with temperature is graphically shown in Figure 2. Figure 2 depicts that the sign of $(\partial B / \partial T)_{\mathrm{P}}$ is positive for all the amino acids/peptides, suggesting that
Table 4. Values of enthalpies $\Delta H^{*}$, entropies $\Delta S^{*}$, and standard error of glycine, diglycine, and triglycine in aqueous

\begin{tabular}{|c|c|c|c|c|}
\hline $\begin{array}{c}\mathrm{m} \\
\left(\mathrm{mol} \mathrm{kg}^{-1}\right)\end{array}$ & $\begin{array}{c}\Delta H^{*} \\
\left(\mathrm{~kJ} \mathrm{~mol}^{-1}\right)\end{array}$ & $\begin{array}{l}\text { Std. } \\
\text { Err. }\end{array}$ & $\begin{array}{c}\Delta S^{*} \\
\left(\mathrm{~J} \mathrm{~mol}^{-1} \mathrm{~K}^{-1}\right)\end{array}$ & $\begin{array}{l}\text { Std. } \\
\text { Err. }\end{array}$ \\
\hline \multicolumn{5}{|c|}{ Gly + aq. Tartrazine } \\
\hline 0.00 & 0.1694 & 0.0031 & 0.0003 & 0.0000 \\
\hline 0.01 & 0.0619 & 0.0343 & -0.0010 & 0.0001 \\
\hline 0.05 & -0.3680 & 0.1825 & -0.0063 & 0.0006 \\
\hline 0.10 & -0.9055 & 0.3678 & -0.0128 & 0.0012 \\
\hline 0.15 & -1.4430 & 0.5531 & -0.0193 & 0.0018 \\
\hline 0.20 & -1.9804 & 0.7384 & -0.0258 & 0.0025 \\
\hline \multicolumn{5}{|c|}{ Digly + aq. Tartrazine } \\
\hline 0.00 & 0.1694 & 0.0031 & 0.0003 & 0.0000 \\
\hline 0.01 & 0.0217 & 0.0277 & -0.0019 & 0.0001 \\
\hline 0.05 & -0.5694 & 0.1292 & -0.0106 & 0.0004 \\
\hline 0.10 & -1.3082 & 0.2562 & -0.0215 & 0.0009 \\
\hline 0.15 & -2.0470 & 0.3831 & -0.0324 & 0.0013 \\
\hline 0.20 & -2.7858 & 0.5101 & -0.0432 & 0.0017 \\
\hline \multicolumn{5}{|c|}{ Trigly + aq. Tartrazine } \\
\hline 0.00 & 0.1694 & 0.0031 & 0.0003 & 0.0000 \\
\hline 0.01 & -0.0332 & 0.0529 & -0.0026 & 0.0002 \\
\hline 0.05 & -0.8436 & 0.2672 & -0.0142 & 0.0009 \\
\hline 0.10 & -1.8567 & 0.5351 & -0.0286 & 0.0018 \\
\hline 0.15 & -2.8698 & 0.8030 & -0.0430 & 0.0027 \\
\hline 0.20 & -3.8828 & 1.0709 & -0.0574 & 0.0036 \\
\hline
\end{tabular}
tartrazine solution at different temperatures.

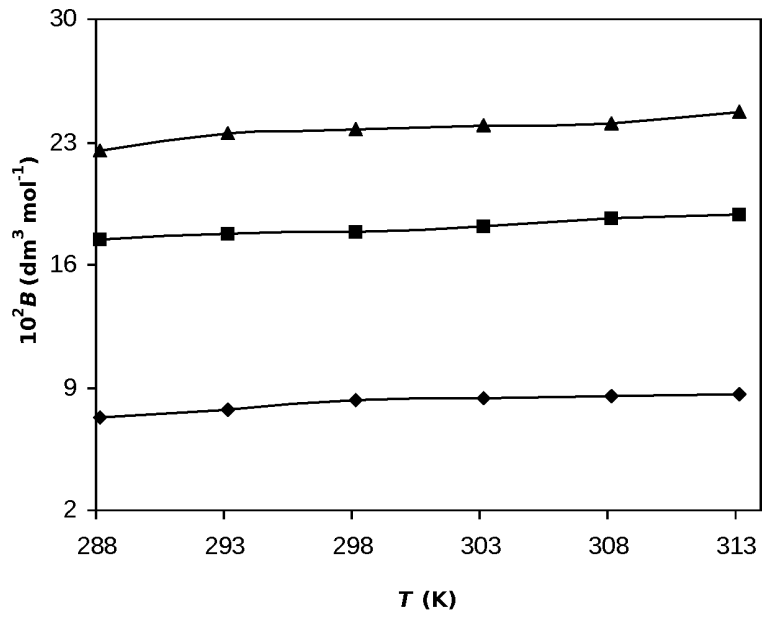

Fig. 2. Plots of $B$ vs $T$ of glycine ( $\bullet$ ), diglycine ( $\mathbf{\square})$, and triglycine $(\mathbf{\Lambda})$ in aqueous tartrazine at different temperatures.

all the amino acid/peptides studied are behaving as net structure-breakers in the presence of aqueous tartrazine. This supports the conclusions drawn by $S_{\mathrm{V}}{ }^{*}$ values.

A close perusal of Table 3 shows that the values of $\Delta \mu_{2}^{0 *}$ are greater than $\Delta \mu_{1}^{0 *}$ values, reflecting that the amino acid/peptide-solvent interaction in the ground state is stronger than in the transition state. The $\Delta \mu_{2}^{0 *}$ values increase from glycine to triglycine im- 


\begin{tabular}{lllllll}
\hline$m\left(\mathrm{~mol} \mathrm{~kg}^{-1}\right)$ & & \multicolumn{7}{c}{$10^{6} R_{\mathrm{D}}\left(\mathrm{m}^{3} \mathrm{~mol}^{-1}\right)$} \\
& $288.15 \mathrm{~K}$ & $293.15 \mathrm{~K}$ & $298.15 \mathrm{~K}$ & $303.15 \mathrm{~K}$ & $308.15 \mathrm{~K}$ & $313.15 \mathrm{~K}$ \\
\hline 0.00 & 3.9421 & 3.9426 & 3.9435 & 3.9441 & 3.9446 & 3.9451 \\
0.01 & 3.9425 & 3.9434 & 3.9447 & 3.9456 & 3.9455 & 3.9464 \\
0.05 & 3.9446 & 3.9453 & 3.9460 & 3.9463 & 3.9476 & 3.9480 \\
0.10 & 3.9473 & 3.9479 & 3.9486 & 3.9493 & 3.9500 & 3.9508 \\
0.15 & 3.9499 & 3.9505 & 3.9516 & 3.9523 & 3.9530 & 3.9536 \\
0.20 & 3.9524 & 3.9531 & 3.9542 & 3.9547 & 3.9555 & 3.9560 \\
& & & Diglycine+ aq. Tartrazine & & \\
0.00 & 3.9421 & 3.9426 & 3.9435 & 3.9441 & 3.9446 & 3.9451 \\
0.01 & 3.9434 & 3.9443 & 3.9466 & 3.9455 & 3.9464 & 3.9484 \\
0.05 & 3.9503 & 3.9527 & 3.9544 & 3.9557 & 3.9570 & 3.9584 \\
0.10 & 3.9629 & 3.9646 & 3.9667 & 3.9685 & 3.9706 & 3.9714 \\
0.15 & 3.9753 & 3.9770 & 3.9802 & 3.9814 & 3.9835 & 3.9843 \\
0.20 & 3.9886 & 3.9907 & 3.9939 & 3.9951 & 3.9973 & 3.9985 \\
0.00 & 3.9421 & 3.9426 & 3.9435 & 3.9441 & 3.9446 & 3.9451 \\
0.01 & 3.9500 & 3.9530 & 3.9573 & 3.9602 & 3.9622 & 3.9621 \\
0.05 & 3.9713 & 3.9757 & 3.9794 & 3.9824 & 3.9858 & 3.9892 \\
0.10 & 3.9960 & 3.9993 & 4.0021 & 4.0059 & 4.0094 & 4.0122 \\
0.15 & 4.0137 & 4.0165 & 4.0213 & 4.0241 & 4.0279 & 4.0308 \\
0.20 & 4.0349 & 4.0377 & 4.0406 & 4.0431 & 4.0450 & 4.0473 \\
\hline
\end{tabular}

Table 5. Values of molar refractive index $R_{\mathrm{D}}$ of amino acids, glycine, diglycine, and triglycine in aqueous tartrazine at different temperatures. plying that as the hydrophobicity of the side chain of amino acid/peptides increases more energy is required in transferring the species from ground to transition state since more solute-solvent bonds are broken to attain the transition state. Similar results were also reported by Pal et al. [27] for amino acids in aqueous urea solutions.

The free energy of activation of viscous flow of solutions $\left(\Delta \mu^{0 *}\right)$ was determined using the equation

$$
\Delta \mu^{0 *}=n_{1} \Delta \mu_{1}{ }^{0 *}+n_{2} \Delta \mu_{2}{ }^{0 *},
$$

where $n_{1}$ and $n_{2}$ are the number of moles of solvent and solute, respectively. The enthalpies $\left(\Delta H^{*}\right)$ and entropies $\left(\Delta S^{*}\right)$ of activation of viscous flow were calculated from the relation [27]

$$
\Delta \mu^{0 *}=\Delta H^{*}-T \Delta S^{*} .
$$

The values of $\Delta H^{*}$ and $\Delta S^{*}$ are obtained from the linear plots of $\Delta \mu^{*}$ vs $T$, as intercept and slope, respectively. These parameters provide useful structural information about solute species and solute-solvent interactions. Their values are given in Table 4. It is observed from Table 4 that $\Delta H^{*}$ values decrease as the concentration of amino acid/peptides increases in the solution, indicating that the formation of the activated species required for viscous flow appears easy as the concentration of solute (amino acid/peptides) increases in the solution. The $\Delta S^{*}$ values are found to be negative

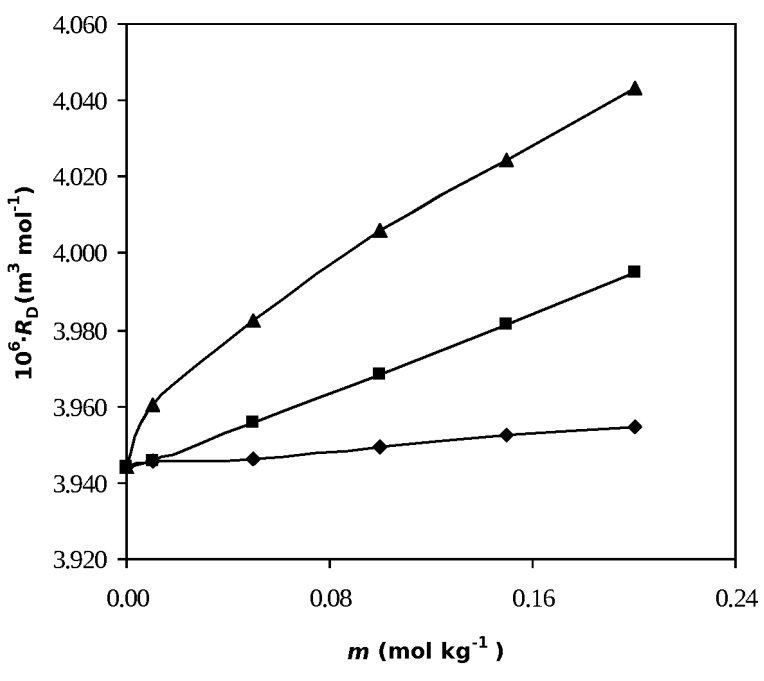

Fig. 3. Plots of $R_{\mathrm{D}}$ vs $m$ of glycine ( $\bullet$ ), diglycine ( $\left.\mathbf{\square}\right)$, and triglycine $(\Delta)$ in aqueous tartrazine at $303.15 \mathrm{~K}$.

and show a pronounced decrease as the concentration of solute increases in the solutions, implying that the system is more structured during the viscous flow than it was in initial state, hence, indicating the presence of significant solute-solvent interactions in the system under investigation.

One of the most versatile tool to elucidate numerous physicochemical and thermophysical properties of multicomponent systems is the use of refractive index. It provides substantial information of the molecular in- 
fluence on the intensity of the interactions in the mixtures.

The refractive index data are fitted into a LorentzLorenz equation to calculate molar refractivity $\left(R_{\mathrm{D}}\right)$ :

$$
R_{\mathrm{D}}=\frac{n_{\mathrm{D}}^{2}-1}{n_{\mathrm{D}}^{2}+2} \sum_{i=1}^{3} \frac{x_{i} M_{i}}{\rho},
$$

where $x_{i}$ is the mole fraction of the $i^{\text {th }}$ component of the mixture having molar mass $M_{i}$. The values of $R_{\mathrm{D}}$ at all investigated temperatures are summarized in Table 5 and plotted in Figure 3 as a functions of amino

[1] G. Rialdi and E. Battistel, Biophysical Chemistry 126, 65 (2007).

[2] A. Ali, S. Hyder, S. Sabir, D. Chand, and A. K. Nain, J. Chem. Thermodyn. 38, 136 (2006).

[3] A. Ali, S. Khan, and S. Hyder, J. Chin. Chem. Soc. 38, 136 (2006).

[4] A. Ali, S. Khan, and S. Hyder, J. Chem. Thermodyn. 39, 613 (2007).

[5] M. L.S. Silna, M. B. Q. Garcia, J. L. F.C. Lima, and E. Barrado, Talanta, 72, 282 (2007).

[6] P.L.L. De Alba, L. L. Martinez, and L. M. De LeonRodriguez, Electroanalysis 14, 117 (2002).

[7] A. Thuvander, Larkartidningin 92, 296 (1995).

[8] S. C. Lockey Sr., Ann. Allergy 38, 206 (1977).

[9] C. Colluis William, J. Asthma Rev. 22, 139 (1985).

[10] J. F. Borjelleca and J. B. Hellagan, Food. Chem. Toxicol. 26, 179 (1988).

[11] M. E. Mac Cana, Can. Med. Assoc. J. 126, 910 (1982).

[12] A. Ali, S. Hyder, S. Khan, and S. Sabir, J. Indian Chem. Soc. 81, 860 (2004).

[13] J. D. Pandey, K. Mishra, A. Shukla, V. Mishran, and R. D. Rai, Thermochim. Acta. 117, 245 (1987).

[14] A. W. Hakin, M. M. Duke, S. A. Klassen, R. M. Mickay, and K.E. Preuss, Can. J. Chem. 72, 362 (1994).

[15] A. W. Hakin, M. M. Duke, L. L. Gnoft, J. L. Marty, and M. L. Rashfeldt, Can. J. Chem. 73, 725 (1995). acid/peptides concentration. The variation of $R_{\mathrm{D}}$ with mixture composition gives information on the interaction in the mixtures [28]. Figure 3 shows that $R_{\mathrm{D}}$ increases almost linearly with increase in the amount of amino acid/peptides in aqueous tartrazine. Since $R_{\mathrm{D}}$ is directly proportional to molecular polarizability, Figure 3 exhibits an increase in overall polarizability of all the ternary systems under study with increasing amount of amino acid/peptides in the mixtures.

It is concluded that the volumetric, viscometric, and refractive index behaviours are in well agreement with each other.

[16] J. Wang, Z. Yan, K. Zhuo, and D. Lie, Z. Phys. Chem. 214, 333 (2000).

[17] J. L. Shen, Z.F. Li, B.H. Wang, and Y.M. Zhang, J. Chem. Thermodyn. 32805 (2000).

[18] A. K. Mishra and J. C. Ahluwalia, J. Phys. Chem. 88, 86 (1984).

[19] T. Ogania, M. Yasuda, and K. Mizutani, Bull. Chem. Soc. Jpn. 57, 2064 (1984).

[20] T. Ogania, M. Yasuda, and K. Mizutani, Bull. Chem. Soc. Jpn. 57, 662 (1984).

[21] T. Banerjee and N. Kishore, J. Solution. Chem. 34, 137 (2005).

[22] A. Ali, S. Sabir, and M. Tariq, Acta. Phys. Chem. Sin. 23, 79 (2007).

[23] G. Jones and M. Dole, J. Am. Chem. Soc. 51, 2950 (1929).

[24] S. Glasstone, K. J. Laidler, and H. Eyring, The Theory of Rate Processes. Mc Graw Hill, New York 1941, pp. 477.

[25] D. Feakins, F. M. Canning, W. E. Waghorne, and K. G. Lawrence, J. Chem. Soc. Faraday Trans. 89, 3381 (1993).

[26] D. Feakins, D. J. Freemantle, and K. G. Lawrence, J. Chem. Soc. Faraday Trans. I. 70, 795 (1974).

[27] A. Pal and S. Kumar, J. Mol. Liq. 109, 23 (2004).

[28] A. D. Aparno, I. D. Donato, and V. T. Leveri, J. Solution Chem. 18, 785 (1989). 